\title{
The Effect of Ground Motion Selection Methods for Seismic Design of Tall Buildings: A Case Study of Mandalay City ${ }^{\dagger}$
}

\section{Yan Naung KO and Teraphan ORNTHAMMARATH*}

\author{
Department of Civil and Environmental Engineering, Faculty of Engineering, Mahidol University, \\ Nakorn Pathom 73170, Thailand
}

('Corresponding author's e-mail: teraphan.orn@mahidol.edu)

Received: 9 June 2019, Revised: 26 January 2020, Accepted: 9 February 2020

\begin{abstract}
The near-fault earthquakes ground motion usually observed a few kilometers away from the active faults generally contains high energetic velocity pulses as a consequence of directivity effects. Mandalay city is located $8 \mathrm{~km}$ away from the Sagaing fault, and the comparative study is conducted to evaluate the structural response of 3 different types of Reinforced Concrete buildings - 4-story, 10-story, and 16-story buildings, respectively. These buildings are subjected to bi-directional ground motions selected from both far-field and pulse-like near-fault earthquakes. The far-field earthquakes produce less seismic demand on the buildings when compared to the near-fault earthquakes, where the ratio of the fundamental period of the building to the pulse period is significant. Comparing 2 ground motion selection and scaling methods of Tall Building Initiative guidelines - TBI (2010) and TBI (2017), the latter approach provides a more meaningful definition of intensity measure and allows reducing some conservatism. The structural response obtained from the design Equivalent Lateral Force (ELF) and Response Spectrum Analysis (RSA) is compared with the code-based linear Response History Analysis (RHA) results.
\end{abstract}

Keywords: Pulse-like ground motion, Near-fault earthquake, Tall Building Initiative (TBI), Intensity measure, Response history analysis, Mandalay

\section{Introduction}

The characteristics of ground motions recorded at the stations which are located in near-fault regions are substantially distinctive compared to the far-field earthquake ground motions. The lessons learned from the past major events indicated the structures located at near-fault regions are more likely to experience severe damage, e.g. the 1971 San Fernando earthquake, the 1994 Northridge earthquake, the 1995 Kobe earthquake, and the 1999 Chi-Chi earthquake. When the fault rupture propagates toward a site at a speed of rupture velocity which is nearly as large as a speed of shear wave velocity, it will undergo forward directivity effect. The substantial amount of seismic energy is conveyed in a single large pulse of motion [1]. There are 2 conditions to occur forward directivity effect: (1) the fault rupture front propagates toward the site, and (2) the direction of slip on the fault is aligned with the site [1]. The nearfault ground motions are characterized by narrower velocity-sensitive regions and wider acceleration- and displacement-sensitive regions. The long-period structures may undergo larger seismic demand when they are subjected to the ground motions with wider acceleration-sensitive region $[2,3]$. Researchers found that the effect of the pulse period $\left(\mathrm{T}_{\mathrm{p}}\right)$ of a ground motion is strongly interrelated with the fundamental vibration period $\left(T_{1}\right)$ of a structure. The building with $T_{1}>T_{p}$ may undergo larger shear

${ }^{\dagger}$ Presented at the $2^{\text {nd }}$ International Symposium on Construction Innovation Research \& PhD Symposium: July 18-19, 2019. 
http://wjst.wu.ac.th

forces in the upper part of the structure while the maximum ductility can be observed in the bottom stories for the building, where $T_{1}$ is less than or equal to $T_{p}$ [4]. In building codes, the 1997 Uniform Building Code (UBC 97) requires to the consideration of the near-source factors when the site is located in the seismic zone IV, and the source-to-site distance is less than $15 \mathrm{~km}$ [5]. The National Earthquake Hazard Reduction Program (NEHRP) defines the near-fault sites as the sites located in a small site-tosource distance less than $20 \mathrm{~km}$ [6]. The ASCE7 (2016) standard specifies that the given site is classified as a near-fault site, if either of these 2 conditions is satisfied: the site is located $15 \mathrm{~km}$ away from a causative fault, which potentially generates moment magnitude $M_{w} 7.0$ or larger events, or the site is located $10 \mathrm{~km}$ away from a causative fault, which potentially generates moment magnitude $\mathrm{M}_{\mathrm{w}} 6.0$ or larger events [7].

Mandalay city is selected as the studied site area, which is the $2^{\text {nd }}$ largest capital city in Myanmar. It is located approximately $8 \mathrm{~km}$ away from the well-known strike-slip fault called the Sagaing fault in the west. It has a higher potential of occurring near-fault earthquakes including the directivity effects along the fault. Myanmar National Building Code 2016 [8] provides the seismic hazard for Mandalay city at the Maximum Considered Earthquake Level (MCE); the response spectral acceleration values at short period $\left(\mathrm{S}_{\mathrm{s}}\right)$ and at $1.0 \mathrm{~s}$ period $\left(\mathrm{S}_{1}\right)$ are $2.01 \mathrm{~g}$ and $0.8 \mathrm{~g}$ respectively. The site class for the studied area is assumed as MNBC site class D (therefore, stiff soil), based on the seismic microzonation report of Mandalay city [9].

\section{Building design and analysis}

In this study, 3 different reinforced concrete buildings - 4-story, 10-story and 16-story are analyzed to observe the effects of different natural vibration periods when subjected to earthquake ground motions. As described in Figure 1, the configuration of the building layout plans for all 3 buildings are the same but different story level. The selected building models are similar to the typical office building type commonly found in Mandalay. The compressive strength of the concrete, $\mathrm{f}_{\mathrm{c}}$ and yield strength of the steel reinforcement $\mathrm{f}_{\mathrm{y}}$ utilized in the analytical models are $28 \mathrm{MPa}$ and $420 \mathrm{MPa}$ respectively. For all buildings, minimum live load $2.4 \mathrm{kN} / \mathrm{m}^{2}$ is used for typical floors, and the roof live load is $1.0 \mathrm{kN} / \mathrm{m}^{2}$. The dead load includes the self-weight of the structure and other additional superimposed dead loads such as partition loads and floor finishing. The buildings are designed as Special Moment Resisting Frames (SMRF) without infill walls in both directions according to MNBC (2016) [8] and ACI (2005) [10]. To account the cracked section analysis, the reduced stiffness factors are applied to the structural elements. The $15 \mathrm{~cm}$ thickness floor slab of the building is monolithically cast with the beams. The inelastic behavior of the structure is considered using the code-based parameters such as response modification factor $(\mathrm{R}=8)$, overstrength factor $(\Omega=3.0)$, and deflection amplification factor $\left(\mathrm{C}_{\mathrm{d}}=5.5\right)$. The buildings used in this study meet the criteria of both horizontal and vertical irregularities. The three dimensional finite element modeling is conducted in ETABS version 16 [11]. The periods and effective modal mass percentages obtained from dynamic modal analysis are summarized in Table 1 for 2 translational X and $\mathrm{Y}$ directions for each building. The sufficient number of modes is considered for Response Spectrum Analysis (RSA) until the $90 \%$ cumulative sum of effective modal mass participation is reached. The interstory drift ratio (IDR) is selected as the engineering demand parameter (EDP) to quantify damage measure (DM) of the structures. The IDR results obtained from code-based linear Response History Analysis (RHA) are compared with Equivalent Lateral Force (ELF) analysis and Response Spectrum Analysis (RSA). Two types of ground motions - near-fault and far-field earthquakes (hereafter referred as 'pulse-like' and 'non pulse-like' respectively) are primarily considered. The effect of ground motion selection methods is studied by comparing 2 Tall Building Initiative guidelines - TBI (2010) [12] and TBI (2017) [13] published by the Pacific Earthquake Engineering Research Center (PEER). 
http://wjst.wu.ac.th

\section{Earthquake ground motions}

\section{Intensity measures (IMs)}

There are several different ways to describe the earthquake ground motion intensity measure (IM). To determine the DM of a structure for a given earthquake, the most commonly used and simple IMs are Peak Ground Displacement (PGD), Peak Ground Velocity (PGV), Peak Ground Acceleration (PGA), and $5 \%$ damped spectral response acceleration $(\mathrm{Sa}(\mathrm{T}), 5 \%)$. The $5 \%$ damped spectral acceleration is the response of elastic single degree of freedom oscillator at $5 \%$ damping, and it can be described in either single arbitrary component or combinations of 2 horizontal orthogonal components. Several definitions are used here to represent the combination of bi-directional horizontal components - (1) Geometric mean of 2 horizontal spectral accelerations $\left(\mathrm{Sa}_{\mathrm{GeoMean}}\right)$, (2) Median spectral acceleration $\left(\mathrm{Sa}_{\mathrm{RotD} 50}\right)$, and (3) Maximum spectral acceleration $\left(\mathrm{Sa}_{\mathrm{RotD} 100}\right)$. The new intensity measures such as $\mathrm{Sa}_{\mathrm{RotD} 100}$ and $\mathrm{Sa}_{\mathrm{RotD} 50}$ are introduced in the NGA-West2 PEER ground motion database. The two as-recorded horizontal acceleration time series are linearly combined into a single time series at each given arbitrary orientation, and the corresponding response spectral acceleration is calculated for each oscillator period. Sa $\mathrm{RotD100}_{\text {is }}$ defined as the maximum spectral acceleration all over the orientations at each vibration period whereas the median value represents $\mathrm{Sa}_{\mathrm{RotD} 50}[14]$.

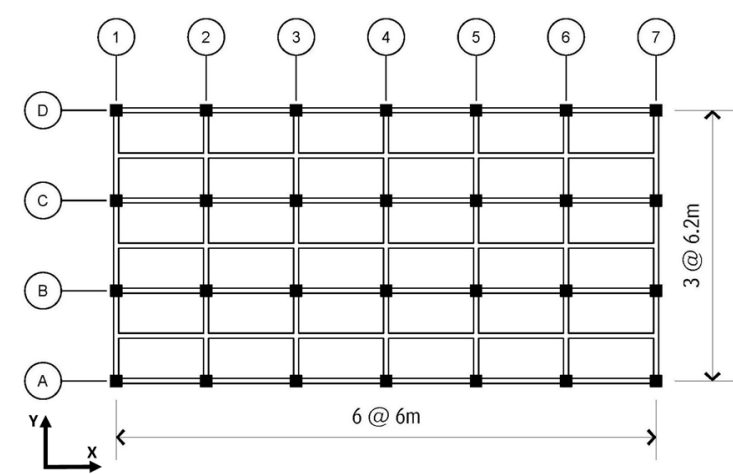

(a)

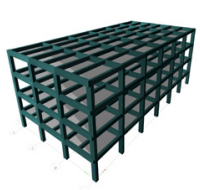

4-Story Building

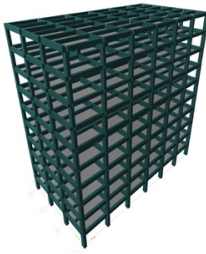

10-Story Building

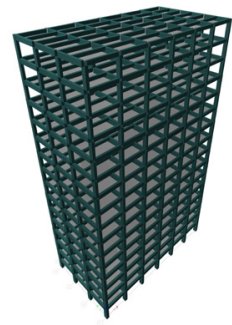

16-Story Building

(b)

Figure 1 (a) Plan view of 3 archetype RC buildings and (b) Isometric view of 3 archetype RC buildings.

Table 1 dynamic property of the buildings in translational directions.

\begin{tabular}{ccccc}
\hline \multirow{2}{*}{ Mode } & \multicolumn{2}{c}{ Period (s) } & \multicolumn{2}{c}{ Effective Modal Mass Percentages (\%) } \\
\cline { 2 - 5 } & $\mathbf{X}$ & $\mathbf{Y}$ & $\mathbf{X}$ & $\mathbf{Y}$ \\
\hline 4-Story Building & & & & \\
1 & 0.83 & 0.69 & 82.6 & 81.7 \\
2 & 0.25 & 0.21 & 11.4 & 11.9 \\
3 & 0.14 & 0.11 & 4.5 & 4.8 \\
\hline 10-Story Building & & & & 76.9 \\
1 & 1.51 & 1.46 & 76.8 & 11.5 \\
2 & 0.56 & 0.51 & 11.9 & 4.4 \\
3 & 0.32 & 0.29 & 4.6 & 73.0 \\
\hline 16-Story Building & & & & 13.3 \\
1 & 2.13 & 2.11 & 73.3 & 4.6 \\
2 & 0.81 & 0.77 & 12.8 & \\
3 & 0.48 & 0.45 & 5.0 &
\end{tabular}




\section{Ground motion selection and scaling}

The earthquake ground motions are selected using the web-based PEER NGA-West2 database, supported by PEER center. The selection process is constrained by several criteria including shear wave velocity, range of scaling factors (maximum 4.0), site condition, style of faulting, and site-to-source distance. The magnitude $\mathrm{M}_{\mathrm{w}} 5.5$ to 8 earthquakes produced by the strike-slip faults are selected because the scenario seismic source in this study is the strike-slip fault type. For near-fault ground motions (pulselike), the site-to-source distance is $0 \mathrm{~km}$ to $15 \mathrm{~km}$ range whereas the earthquakes occurred within the range of $100 \mathrm{~km}$ radius are selected for far-field ground motions (non pulse-like), in which the velocity pulse is intentionally excluded. There are 4 different ground motion sets for each building; (a) TBI-2010 non pulse-like ground motions set, (b) TBI-2017 non pulse-like ground motions set, (c) TBI-2010 pulselike ground motions set, and (d) TBI-2017 pulse-like ground motions set, as shown in Figure 2. In selecting and identifying the near-fault ground motions, the quantitative classification algorithm $[15,16]$ is employed to extract the dominant velocity pulse from the velocity time series. The algorithm incorporates the wavelet analysis, which breaks down the whole signal into several wavelets. The pulseperiod $\left(T_{p}\right)$ is defined as the pseudo-period of a wavelet which has the maximum Fourier amplitude. The pulse periods associated with the ground motions used in this study are listed in Table 2 .

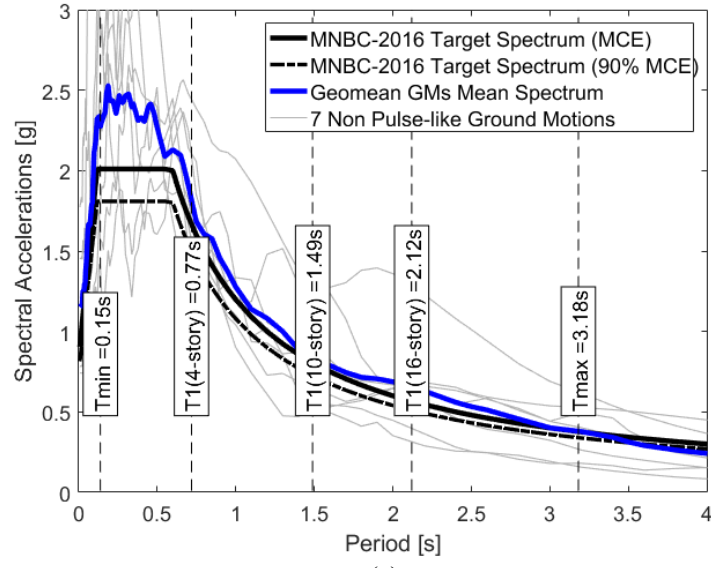

(a)

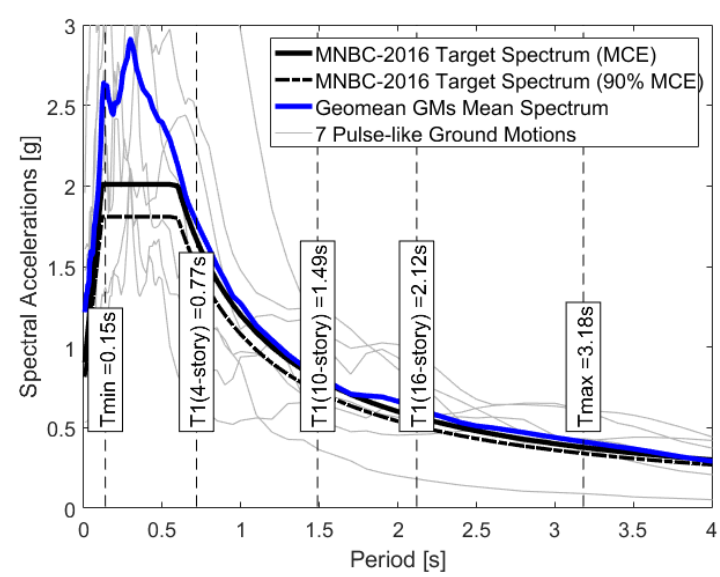

(c)

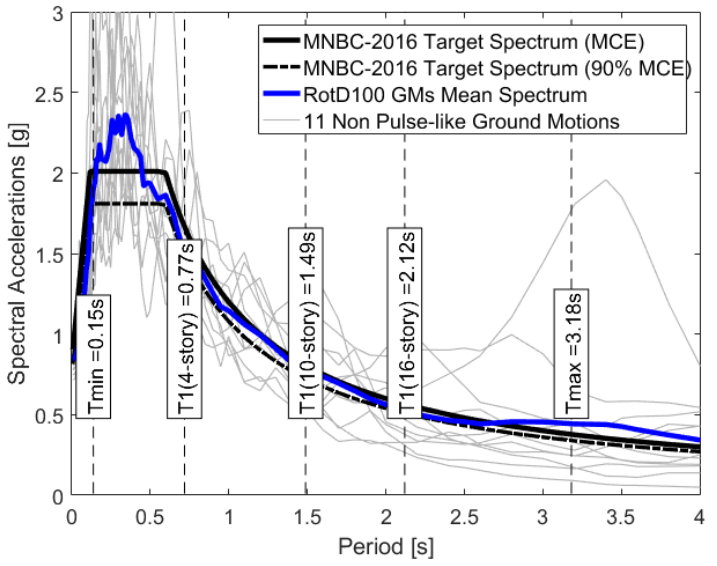

(b)

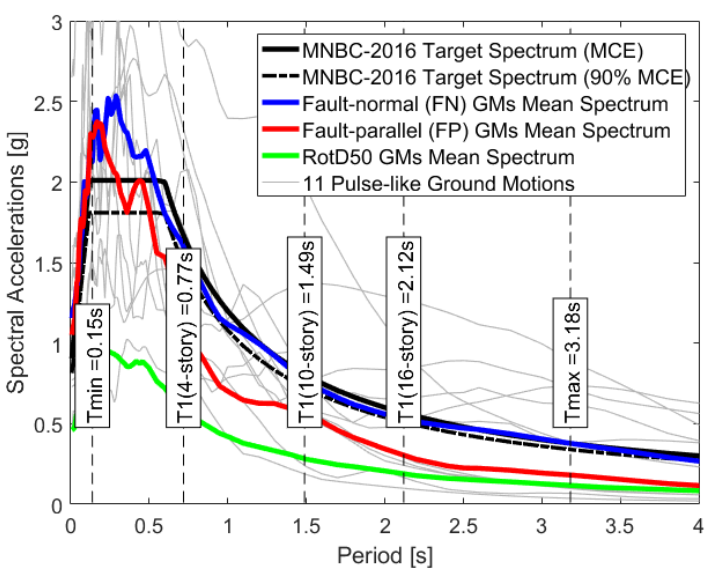

(d)

Figure 2 (a) TBI (2010) non pulse-like ground motions set (b) TBI (2017) non pulse-like ground motions set (c) TBI (2010) pulse-like ground motions set (d) TBI (2017) pulse-like ground motions set. 
http://wjst.wu.ac.th

TBI (2010) approach

In TBI (2010) ground motions sets, at least 7 ground motions are used for both near-fault and farfield earthquakes. The pulse-like ground motions are rotated to fault-normal (FN) direction and the average spectrum is considered in terms of geometric means of these 2 rotated components. The geometric means of as-recorded horizontal components are used to match with the target spectrum for non pulse-like. The amplitude scaling method is used for both TBI (2010) and TBI (2017) sets within the target period range of interest $-0.2 \mathrm{~T}_{1}$ to $1.5 \mathrm{~T}_{1}$, where $\mathrm{T}_{1}$ denotes the fundamental period. For scaling the ground motions, the target period is taken as the average fundamental period value $\left(\mathrm{T}_{\text {avg }}\right)$ of $\mathrm{X}$ - and $\mathrm{Y}$ directions of a building [6].

Table 2 Selected earthquake ground motions.

\begin{tabular}{|c|c|c|c|c|c|c|c|c|c|}
\hline \multirow{2}{*}{ No. } & \multirow{2}{*}{ Record } & \multirow{2}{*}{ Earthquake } & \multirow{2}{*}{ Year } & \multirow{2}{*}{$\mathbf{M}_{\mathbf{w}}{ }^{1}$} & \multirow{2}{*}{$\begin{array}{l}\mathbf{T} \mathbf{p}^{2} \\
\text { (s) }\end{array}$} & \multirow{2}{*}{$\begin{array}{c}\operatorname{Rrup}^{3} \\
\text { (km) }\end{array}$} & \multirow{2}{*}{$\begin{array}{l}\text { Vs30 } \\
\text { (m/s) }\end{array}$} & \multicolumn{2}{|c|}{ Scale Factor } \\
\hline & & & & & & & & TBI 2010 & TBI 2017 \\
\hline \multicolumn{10}{|c|}{ Non pulse-like ground motions } \\
\hline 1 & 6 & Imperial Valley 02 & 1940 & 6.9 & - & 6.1 & 213 & 3.0 & - \\
\hline 2 & 95 & Managua Nicaragua 01 & 1972 & 6.2 & - & 4.1 & 289 & 2.9 & - \\
\hline 3 & 165 & Imperial Valley 06 & 1979 & 6.5 & - & 7.3 & 242 & 3.0 & - \\
\hline 4 & 169 & Imperial Valley 06 & 1979 & 6.5 & - & 22.0 & 242 & 3.7 & 2.7 \\
\hline 5 & 183 & Imperial Valley 06 & 1979 & 6.5 & - & 3.9 & 206 & 3.3 & - \\
\hline 6 & 725 & Superstition Hills 02 & 1987 & 6.5 & - & 11.2 & 317 & 3.9 & - \\
\hline 7 & 821 & Erzican & 1992 & 6.7 & - & 4.4 & 352 & 2.8 & - \\
\hline 8 & 902 & Big Bear 01 & 1992 & 6.5 & - & 40.5 & 359 & - & 3.5 \\
\hline 9 & 1634 & Manjil & 1990 & 7.4 & - & 75.6 & 303 & - & 3.3 \\
\hline 10 & 3756 & Landers & 1992 & 7.3 & - & 40.7 & 368 & - & 3.8 \\
\hline 11 & 5832 & El Mayor Cucapah & 2010 & 7.2 & - & 26.6 & 242 & - & 3.3 \\
\hline 12 & 5990 & El Mayor Cucapah & 2010 & 7.2 & - & 27.9 & 211 & - & 3.3 \\
\hline 13 & 6013 & El Mayor Cucapah & 2010 & 7.2 & - & 28.3 & 276 & - & 3.5 \\
\hline 14 & 6923 & Darfield & 2010 & 7.0 & - & 30.5 & 255 & - & 2.5 \\
\hline 15 & 6953 & Darfield & 2010 & 7.0 & - & 24.6 & 206 & - & 3.2 \\
\hline 16 & 6971 & Darfield & 2010 & 7.0 & - & 29.9 & 390 & - & 3.7 \\
\hline 17 & 8160 & El Mayor Cucapah & 2010 & 7.2 & - & 35.5 & 210 & - & 3.3 \\
\hline \multicolumn{10}{|c|}{ Pulse-like ground motions } \\
\hline 18 & 171 & Imperial Valley 06 & 1979 & 6.5 & 3.42 & 0.1 & 265 & 3.2 & 2.2 \\
\hline 19 & 184 & Imperial Valley 06 & 1979 & 6.5 & 6.27 & 5.1 & 202 & 3.6 & 3.4 \\
\hline 20 & 185 & Imperial Valley 06 & 1979 & 6.5 & 4.82 & 7.5 & 203 & 3.8 & 3.1 \\
\hline 21 & 1119 & Kobe & 1995 & 6.9 & 1.81 & 0.3 & 312 & - & 2.4 \\
\hline 22 & 1602 & Duzce & 1999 & 7.1 & 0.88 & 12.0 & 294 & 3.2 & 0.7 \\
\hline 23 & 4098 & Parkfield 02 & 2004 & 6.0 & 1.33 & 3.0 & 327 & - & 1.8 \\
\hline 24 & 4101 & Parkfield 02 & 2004 & 6.0 & 0.52 & 5.6 & 397 & - & 2.3 \\
\hline 25 & 4102 & Parkfield 02 & 2004 & 6.0 & 1.02 & 3.6 & 231 & 3.8 & 2.9 \\
\hline 26 & 4126 & Parkfield 02 & 2004 & 6.0 & 0.57 & 3.8 & 261 & - & 3.1 \\
\hline 27 & 6960 & Darfield & 2010 & 7.0 & 9.39 & 13.6 & 293 & 2.6 & 3.8 \\
\hline 28 & 6975 & Darfield & 2010 & 7.0 & 8.93 & 6.1 & 249 & 3.8 & 3.5 \\
\hline 29 & 6911 & Darfield & 2010 & 7.0 & 9.92 & 7.3 & 326 & - & 1.4 \\
\hline 30 & 6927 & Darfield & 2010 & 7.0 & 7.37 & 7.1 & 263 & - & 1.4 \\
\hline
\end{tabular}

1. The moment magnitude; 2. Pulse period; 3 . Closet rupture distance; 4. Average shear wave velocity (subsurface depth of $30 \mathrm{~m})$ 
http://wjst.wu.ac.th

\section{TBI (2017) approach}

In TBI (2017), the maximum-direction response spectra need to be scaled at least equaling to $90 \%$ of the target spectrum within the period range of interest. Sa $a_{\text {RotD100 }}$ maximum response spectrum is used for non pulse-like ground motions set. In pulse-like ground motions set, the fault-normal component is taken as the maximum-direction, and the 2 as-recorded horizontal ground motions are rotated to faultnormal (FN) and fault-parallel (FP) directions, respectively. The average fault-parallel components are ensured not to fall below the average $\mathrm{Sa}_{\mathrm{RotD} 50}$ spectrum of that ground motions. 11 ground motions are considered to fulfill the minimum requirement of ground motions for response history analysis. To be consistent with the $1^{\text {st }}$ approach, the same scaling method and target period range of interest is maintained.

\section{Results and discussion}

The major components of ground motions such as fault-normal component (FN) and as-recorded $1^{\text {st }}$ component are typically applied to X-direction while applying orthogonal components in Y-direction of the buildings. It was found that the pulse-like ground motions generally caused higher seismic demand compared to the non pulse-like ground motions in X-direction of the building, where the major components were applied. Using the same scale factor of ground motions, each building underwent different seismic demand depending on the ratio of the fundamental period of a building to pulse period $\left(T_{1} / T_{p}\right)$ in near-fault earthquakes. As depicted in Figures 3(a), 4(a) and 5(a), the $T_{1} / T_{p}$ ratios of 16-story, 10 -story and 4-story building for Duzce earthquake (record 1602) are 2.4, 1.7, and 0.8 respectively. In 16story building, the IDR was higher in the upper stories compared to the bottom stories, where the IDR was lower and constant along the height. This behavior was less noticeable in 10 -story building with a slightly lower ratio. When it came to the $T_{1} / T_{p}$ ratio closed to the fundamental period $\left(T_{1}\right)$ of the 4-story building, the seismic demand was more pronounced in middle and bottom stories of the building, and this particular ground motion was more likely to have large effects to short-period buildings compared to the above 2 long-period structures. The same behavior of higher seismic demand in the upper stories was observed in the Parkfield earthquake records such as 4101, 4102, and 4126, which had larger $\mathrm{T}_{1} / \mathrm{T}_{\mathrm{p}}$ ratios for the 16-story building. In ELF analysis, the base shear was calculated based on the fundamental period $\left(\mathrm{T}_{1}\right)$ directly obtained from modal analysis. The IDR obtained from different analysis sets were compared for 3 buildings, as illustrated in Figures 3(b), 4(b), and 5(b) respectively. The distribution of IDR obtained from ELF follows the similar pattern of RSA analysis along the height of the building in 4-story and 10-story buildings. The IDR difference between ELF and RSA was more tangible in the 16-story building. Comparing the 2 ground motion modification methods, TBI-2017 adapted the maximumdirection IM. Allowing a certain extent of flexibility in matching the target spectrum, TBI-2017 reduced some conservatism by providing a more meaningful definition of intensity measure rather than in terms of the average spectrum. The results indicated that TBI (2017) sets produced less seismic demand compared to TBI (2010) sets in both $\mathrm{X}$ - and Y- directions. For non pulse-like ground motions, the maximum structural response was not always consistent with the major component direction of the ground motions. It was observed that the $\mathrm{Y}$-direction response was fairly higher than X-direction in set (a). 

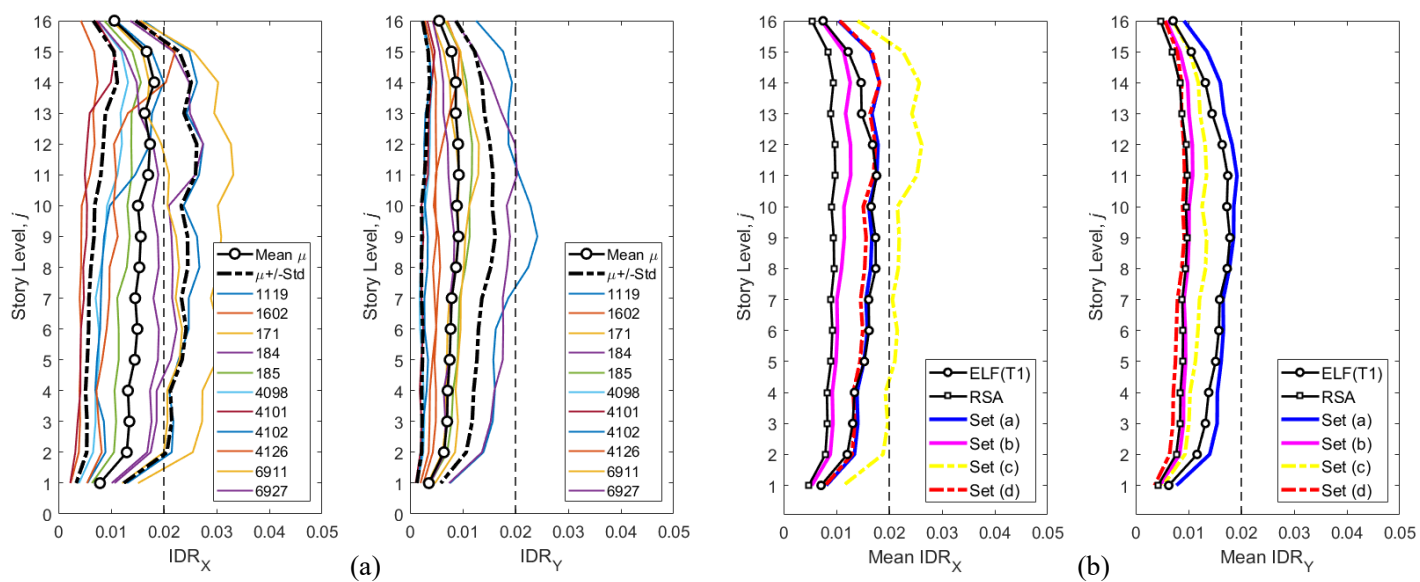

Figure 3 (a) IDR of TBI-2017 pulse-like set and (b) Comparison of mean IDR for 16-story building.
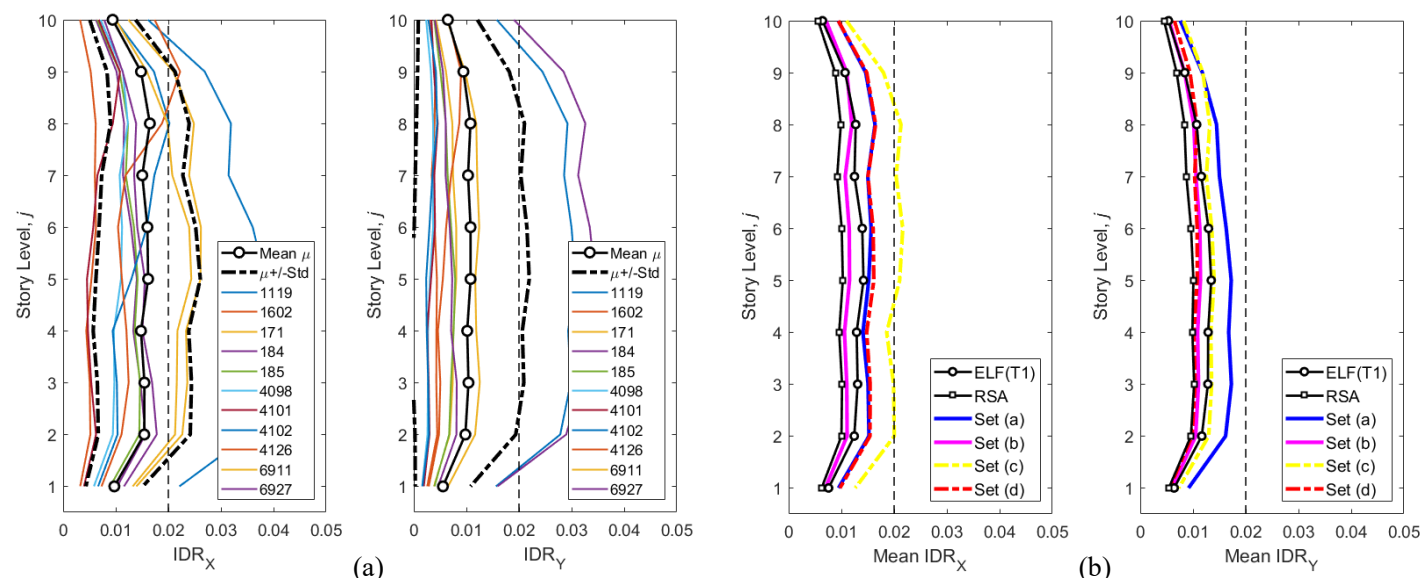

Figure 4 (a) IDR of TBI-2017 pulse-like set and (b) Comparison of mean IDR for 10-story building.
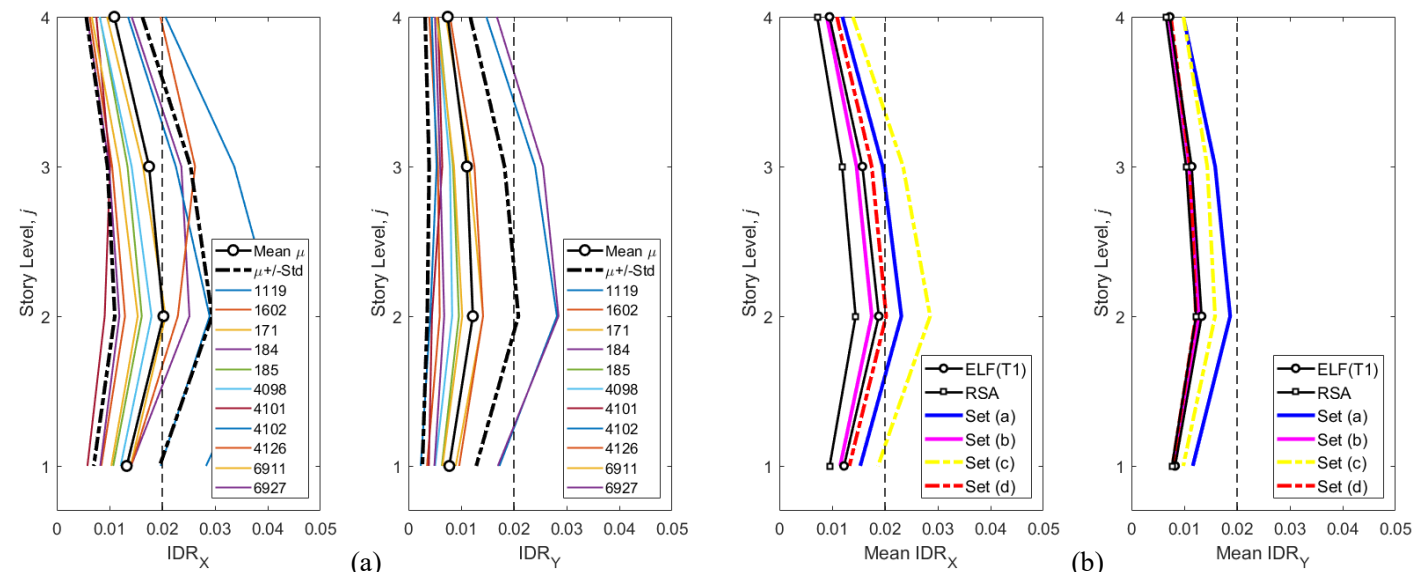

Figure 5 (a) IDR of TBI-2017 pulse-like set and (b) Comparison of mean IDR for 4-story building. 
http://wjst.wu.ac.th

\section{Conclusions}

The significance of $T_{1} / T_{p}$ ratio in near-fault earthquakes in previous study [4] was extended into 3dimensional linear analysis by using regular multi-story RC buildings, as discussed in the current study. TBI (2010) ground motions sets produced rather conservative results. In TBI (2017) approach, analyzing more ground motions could be more computationally expensive to a certain extent, and several steps were added in the stage of ground motions processing because it was necessary to rotate the as-recorded ground motions, and to construct the maximum-direction response spectrum. However, at the expense of the extensive ground motion selection process, the variability of different ground motion characteristics could be used in structural analysis and design. It gave a more accurate and reliable structural response on buildings due to its period-dependent maximum spectral acceleration on corresponding orientation.

\section{References}

[1] PG Somerville, NF Smith, RW Graves and NA Abrahamson. Modification of empirical strong ground motion attenuation relations to include the amplitude and duration effects of rupture directivity. Seismologic. Res. Lett. 1997; 68, 199-222.

[2] AK Chopra and C Chintanapakdee. Comparing response of SDF systems to near-fault and far-fault earthquake motions in the context of spectral regions. Earthquake Eng. Struct. Dynam. 2001; 30, 1769-89.

[3] PK Malhotra. Response of buildings to near-field pulse-like ground motions. Earthquake Eng. Struct. Dynam. 1999; 28, 1309-26.

[4] B Alavi and H Krawinkler. Behavior of moment-resisting frame structures subjected to near-fault ground motions. Earthquake Eng. Struct. Dynam. 2004; 33, 687-706.

[5] International Conference of Building Officials. Uniform building code. In: Proceedings of the International Conference of Building Officials, 1997.

[6] A Whittaker, G Atkinson, J Baker, J Bray, D Grant, R Hamburger, C Haselton and P Somerville. Selecting and Scaling Earthquake Ground Motions for Performing Response-History Analyses. NIST (No. Grant/Contract Reports (NISTGCR)-11-917-15), 2011.

[7] ASCE/SEI 7-16. Minimum Design Loads for Buildings and Other Structures. American Society of Civil Engineers, Reston, VA, 2016.

[8] Myanmar Engineering Council. Myanmar National Building Code. Myanmar Engineering Council, 2016.

[9] PS Thein, J Kiyono, TT Win, TT Nu and DW Aung. Seismic Microzonation of Mandalay City, Myanmar. J. Geologic. Resour. Eng. 2018; 6, 1-13.

[10] ACI Committee. Building Code Requirements for Structural Concrete (ACI 318-05) and Commentary (ACI 318R-05). American Concrete Institute, 2005.

[11] C CSI. Analysis Reference Manual for SAP2000, ETABS, and SAFE. Computers and Structures, Berkeley, California, USA, 2016.

[12] Pacific Earthquake Engineering Research Center. Guidelines for Performance-based Seismic Design of Tall Buildings. Pacific Earthquake Engineering Research Center, College of Engineering, University of California, 2010.

[13] Pacific Earthquake Engineering Research Center. Guidelines for Performance-based Seismic Design of Tall Buildings. Pacific Earthquake Engineering Research Center, College of Engineering, University of California, 2017.

[14] DM Boore, J Watson-Lamprey and NA Abrahamson. Orientation-independent measures of ground motion. Bull. Seismologic. Soc. Amer. 2006; 96, 1502-11.

[15] JW Baker. Quantitative classification of near-fault ground motions using wavelet analysis. Bull. Seismologic. Soc. Amer. 2007; 97, 1486-501.

[16] SK Shahi and JW Baker. An efficient algorithm to identify strong-velocity pulses in multicomponent ground motions. Bull. Seismologic. Soc. Amer. 2014; 104, 2456-66. 